\title{
Effects of Oil Drops and the Charcoal's Proximate Composition on the Air Pollution Emitted from Charcoal Barbecues
}

\author{
Kuo-Pin Yu ${ }^{1 *}$, Yen-Chi Chen ${ }^{1}$, Yun-Jhe Miao ${ }^{2}$, Sepridawati Siregar ${ }^{3,4}$, Yu Wei Tsai ${ }^{1}$, \\ Whei-May Grace Lee 2** $^{* *}$ \\ ${ }^{1}$ Institute of Environmental and Occupational Health Sciences, National Yang-Ming University, Taipei 11221, Taiwan \\ ${ }^{2}$ Graduate Institute of Environmental Engineering, National Taiwan University, Taipei 10617, Taiwan \\ ${ }^{3}$ Institute of Public Health, National Yang-Ming University, Taipei 11221, Taiwan \\ ${ }^{4}$ Institut Sains \& Teknologi AKPRIND, Yogyakarta 55222, Indonesia
}

\begin{abstract}
This research investigated the emission rates (ERs) and emission factors (EFs) of air pollutants generated from charcoal barbecues and the influence of temperature, the charcoal's proximate composition (moisture, volatile matter, fixed carbon, and ash), and oil drops. Charcoal briquettes, longan charcoal, and binchotan (commonly used for indoor barbecues) were selected for combustion experiments, and the exhaust gas was collected for the analysis of air pollutants, viz., $\mathrm{CO}_{2} \mathrm{CO}_{2}$, $\mathrm{NO}_{x}$, hydrocarbons (HCs), benzene, toluene, formaldehyde, acetaldehyde, $\mathrm{PM}_{2.5}$, and trace metals ( $\mathrm{Al}, \mathrm{Cr}, \mathrm{Cu}, \mathrm{Fe}$, and $\mathrm{Zn}$ ). A linear regression model was employed to verify the major factors affecting the EFs.

The EFs of HCs measured during the dripping of oil and sauce on the charcoal ranged from 2486.2 to $9305.2 \mathrm{mg} \mathrm{kg}^{-1}$, 76.4-357\% higher than those measured during no dripping. For $\mathrm{PM}_{2.5}$, the EFs measured during dripping ranged from 3080.4 to $3926.5 \mathrm{mg} \mathrm{kg}^{-1}, 8-19$ times higher than those measured during no dripping. The EFs of benzene, toluene, formaldehyde, and acetaldehyde also significantly increased during dripping. In addition, increasing the combustion temperature reduced the EFs of HCs, formaldehyde, and CO but increased those of Fe and $\mathrm{Zn}$. The charcoal moisture content was significantly positively correlated with the EF of $\mathrm{HCs}$, whereas the volatile matter content was significantly positively correlated with those of HCs and benzene. Positive correlations existed between the charcoal ash content and the EFs of CO, Fe, and Zn. The fixed carbon content was significantly positively correlated with the EF of $\mathrm{CO}_{2}$ but negatively correlated with those of $\mathrm{CO}, \mathrm{Al}$, and $\mathrm{Zn}$.
\end{abstract}

Keywords: Charcoal barbecue; Air pollution; Emission factor; $\mathrm{PM}_{2.5}$.

\section{INTRODUCTION}

Worldwide, approximately 2.8 billion people (approximately half of the world's population) rely on solid fuels, including wood, charcoal, coal, crop residues, bamboo, and animal dung, for cooking, particularly in developing countries (Jetter and Kariher, 2009; Bonjour et al., 2013; Huangfu et al., 2014). According to the first comparative risk assessment of the Global Burden of Disease project (Smith et al., 2004), cooking with solid fuels has led to approximately 2 million

\footnotetext{
* Corresponding author.

Tel.: 886-2-28267933

E-mail address: kpyu@ym.edu.tw

** Corresponding author.

Tel.: 886-2-33664382

E-mail address: gracelee@ntu.edu.tw
}

premature deaths from pneumonia, chronic obstructive pulmonary disease and other respiratory diseases (WHO, 2017). Based on the newest available data, in 2016, 2.6 million global deaths resulted from illnesses were attributed to household air pollution from burning solid fuel (Institute for Health Metrics and Evaluation, 2017). Solid fuel cooking has also caused considerable outdoor air pollution in many regions and, consequently, it has been associated with approximately 0.5 million more premature deaths (Lim et al., 2012).

Emissions from cooking activities can have detrimental impacts on aerosols and air quality at regional and global scales. The measurement of air pollutants, such as particulate matter (PM) and trace gases, can enable the quantification of the impact of cooking and biomass burning on regional air pollutant concentrations. For example, daily $\mathrm{PM}_{2.5}$ filter samples were collected in Navrongo, Ghana, from 20092010 (Ofosu et al., 2013); using source apportionment techniques, observed particulate elemental carbon (EC) and 
organic carbon (OC) and speciated elements were used to identify sources of $\mathrm{PM}_{2.5}$, and biomass combustion was found to be the second-largest contributor to ambient PM concentrations after dust. Regional $\mathrm{PM}_{2.5}$ monitoring has also been performed in Accra (Rooney et al., 2012); Nigeria (Obioh et al., 2013); Ouagadougou, Burkina-Faso (Boman et al., 2009); and Cairo (Abu-Allaban et al., 2007).

In developed countries, household solid fuel cooking is uncommon. However, charcoal barbecues (BBQs) are very popular, and barbecuing has become a common leisure activity. Charcoal BBQs are used both outdoors and indoors. For example, in Taiwan, the number of indoor charcoal BBQ restaurants is increasing, and there are even indoor barbecue chain stores. The air pollution emitted from BBQs not only results in the deterioration of indoor air quality but also severely impacts outdoor air quality. Many studies have found that charcoal BBQs are one of the major sources of air pollutants, including $\mathrm{PM}$, carbon monoxide (CO), nitrogen oxides $\left(\mathrm{NO}_{x}\right)$, volatile organic compounds (VOCs), carbonyls, trace metals, and polycyclic aromatic hydrocarbons (PAHs) (Venkataraman and Rao, 2001; Bhattacharya et al., 2002b; Jetter and Kariher, 2009; Kabir et al., 2010, 2011; Huang et al., 2016).

Taner et al. (2013) found that the total hazard quotient (total HQ) and excess lifetime cancer risk (total ELCR) from exposure to metal elements on the fine PM in indoor barbecue restaurants were higher than the acceptable level. Susaya et al. (2010) also found that the concentrations of many trace metals emitted from BBQ charcoal combustion exceeded the permissible exposure limits (PELs) (Iqbal and Kim, 2016). Not only the concentration of trace metal elements but also the concentration of PM exceeded the PELs, as demonstrated in a review by Iqbal and Kim (2016). Although the VOCs and carbonyls emitted from BBQ charcoal combustion may not exceed the PELs (Kabir et al., 2010), offensive odorants including VOCs, carbonyls, reduced sulfur compounds and ammonia sometimes exceed the reference guidelines (Mahmudur Rahman and Kim, 2012). Badyda et al. (2017) investigated the inhalation exposure to particle-bound PAHs released from BBQ grills powered by gas, lump charcoal, and charcoal briquettes. They found that the PM emission concentrations from BBQ grills with food loaded were much higher than those without food loaded. The incremental lifetime cancer risk due to particle-bound PAH exposure ranged from as low as $8.38 \times 10^{-5}$ (gas without food load) to as high as 0.868 (charcoal briquettes with food load). Therefore, we suspected that the oil drops (and BBQ sauce) from barbecued foods, which usually instantly emit extremely high concentrations of smoke, contribute most of the air pollutants during charcoal BBQs. However, this issue was not previously investigated. In addition, although charcoal emissions have been reported in many previous studies, most of the studies involved descriptive research without systematic statistical analysis and did not provide results about what kinds of factors influence the air pollution emitted from charcoal BBQs. One innovative approach in our study is that we utilized a linear regression model to determine the major factors influencing the emission of air pollutants during the combustion of charcoal.
Our previous study (Huang et al., 2016) evaluated the emission factors (EFs) of $\mathrm{PM}_{2.5}, \mathrm{PM}_{10}$, hydrocarbons (HCs), $\mathrm{CO}, \mathrm{CO}_{2}, \mathrm{NO}_{x}$, formaldehyde and acetaldehyde from ten charcoals used in both indoor and outdoor BBQs in Taiwan. As a follow-up study, the primary objective of this study is to investigate the effects of oil dripping from food on air pollutants, namely, $\mathrm{CO}$, carbon dioxide $\left(\mathrm{CO}_{2}\right)$, total $\mathrm{HCs}$, $\mathrm{NO}_{x}$, carbonyls (formaldehyde and acetaldehyde), aromatic HCs (benzene and toluene), $\mathrm{PM}_{2.5}$ (particles smaller than $2.5 \mu \mathrm{m}$ ), and $\mathrm{PM}_{2.5}$ metals, emitted from commonly used BBQ charcoal and to determine the pollutant EFs. Basic experiments involving the determination of charcoal characteristics, including the heating value and the contents of moisture, volatiles, fixed carbon, and ash, and elemental analysis, were also undertaken. Combustion experiments investigating three common charcoals, i.e., charcoal briquettes, longan charcoal, and binchotan, were performed under different combustion temperatures with or without oil dripping. The flue gas from the combustion was collected and analyzed for $\mathrm{PM}_{2.5}$ and the gaseous air pollutants $\mathrm{CO}, \mathrm{CO}_{2}$, $\mathrm{NO}_{x}$, and total HCs. Understanding the characteristics and EFs of pollutants emitted from charcoal BBQs can help formulate better control strategies and predict the impact of charcoal BBQs on both indoor and ambient air quality.

\section{MATERIALS AND METHODS}

\section{Experimental Design}

Three kinds of charcoal commonly used for indoor barbecuing in Taiwan were selected for combustion experiments (Table 1). The charcoals utilized in this study were cut into small pieces (20-40 mm). Before combustion, the charcoal was conditioned in a drying cabinet at room temperature and relative humidity below $50 \%$ for 24 hours. For each batch combustion experiment, $30 \pm 0.5 \mathrm{~g}$ of the conditioned charcoal was burned at two different temperature settings $\left(425^{\circ} \mathrm{C}\right.$ and $\left.500^{\circ} \mathrm{C}\right)$ to simulate charcoal combustion at high temperatures during a BBQ. The air flow rate passing through the combustion chamber was set at $10 \mathrm{~L} \mathrm{~min}^{-1}$, corresponding to a face velocity of $8.5 \mathrm{~cm} \mathrm{~s}^{-1}$, which meets the excellent-grade indoor air flow standard $\left(<20 \mathrm{~cm} \mathrm{~s}^{-1}\right)$ recommended by the indoor air quality guidelines of Hong Kong. The ventilation rate of the combustion chamber was $17 \mathrm{~min}^{-1}$, which provided sufficient air and oxygen for charcoal combustion. In addition, the dripping of oil and BBQ sauce from the barbecued meat to the burned charcoals was simulated. A total of $3 \pm 0.05 \mathrm{~g}$ of lard oil, BBQ sauce, or a mixture of lard oil and BBQ sauce (1:1) was added to the charcoal. The whole sampling time of airborne pollutants from the combustion was 60 minutes. After 1 hour, the charcoal flames were extinguished. The remaining unburned charcoal was conditioned again and then weighed. All experiments were carried out in triplicate. The air pollutants produced from charcoal combustion investigated in this study included $\mathrm{PM}_{2.5}$, the heavy metals in $\mathrm{PM}_{2.5}, \mathrm{HCs}, \mathrm{CO}$, $\mathrm{CO}_{2}, \mathrm{NO}_{x}$, benzene, toluene, formaldehyde, and acetaldehyde. The emission rates (ERs) and EFs of the measured air pollutants emitted by combustion were calculated by Eqs. (1) and (2) based on the analytical results. 
Table 1. Charcoal characteristics.

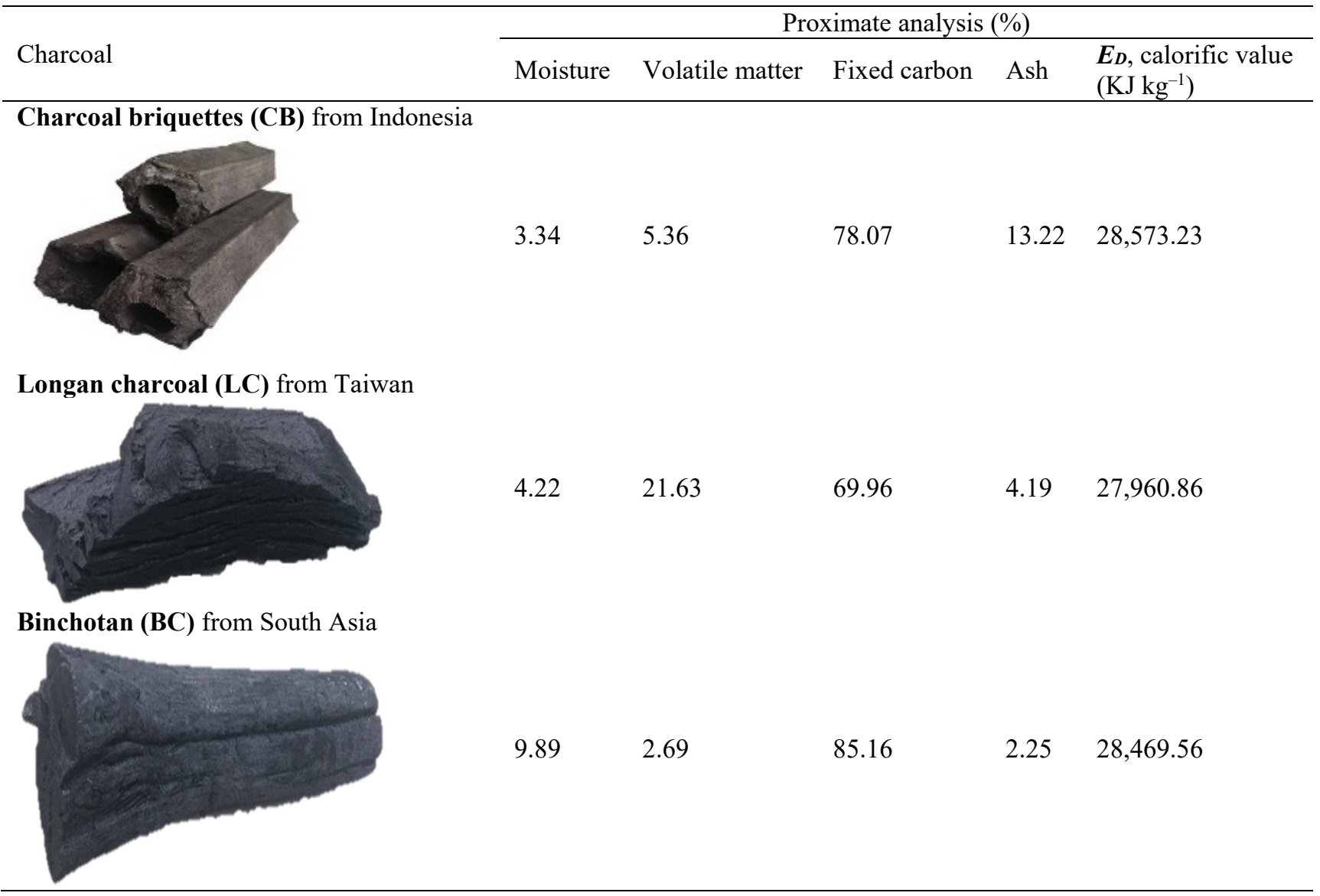

$E R=\sum_{i=1}^{n} C_{i} Q_{i} t_{i}$

$$
E F=\frac{\sum_{i=1}^{n} C_{i} Q_{i} t_{i}}{m_{o}-m_{f}} \times 10^{3}
$$

Here, $\mathrm{C}_{\mathrm{i}}$ is the air pollutant concentration $\left(\mathrm{mg} \mathrm{Nm}^{-3}\right)$; $\mathrm{Q}_{\mathrm{i}}$ is the air flow rate passing through the combustion chamber $\left(10 \mathrm{~L} \mathrm{~min}^{-1}=10^{-3} \mathrm{Nm}^{3} \mathrm{~min}^{-1}\right) ; \mathrm{t}_{\mathrm{i}}$ is the sampling time $(60$ minutes); $\mathrm{m}_{0}$ is the weight of charcoal before burning (g); and $\mathrm{m}_{\mathrm{f}}$ is the weight of the remaining unburned charcoal $(\mathrm{g})$. The unburned charcoal is not part of the ash. The ash content was determined by the standard methods NIEA R205.01C and CNS 10822, as described in our previous study (Huang et al., 2016), and the ash was the charcoal residue after burning at $800^{\circ} \mathrm{C}$ for 3 hours. The unburned charcoal was the charcoal residue in our experiments (burning at $425^{\circ} \mathrm{C}$ or $500^{\circ} \mathrm{C}$ for 1 hour).

\section{Experimental Setting}

The schematic of the experimental setup is shown in Fig. 1. An air compressor provided the air for the experimental system. The moisture in the air was removed first by a mist eliminator and then by a diffusion dryer. Then, the organic compounds and PM in the dry output air were eliminated by an activated carbon cartridge and a high-efficiency particulate air (HEPA) filter to produce zero air for the combustion chamber (Model D-55; Deng Yang Instrument Co., Ltd., Taiwan) to perform the charcoal combustion experiments. The combustion chamber $(250 \mathrm{~mm} \times 350 \mathrm{~mm} \times 400 \mathrm{~mm})$ was composed of a tube furnace with front and back stainless-steel doors, a quartz tube, and a quartz carrier. The inner diameter and the effective heating length of the tube furnace were $55 \mathrm{~mm}$ and $300 \mathrm{~mm}$, respectively. The internal and external diameters and the length of the quartz tube were 50,53 , and $1000 \mathrm{~mm}$, respectively. Before the combustion experiments, $30 \pm 0.5 \mathrm{~g}$ of the conditioned charcoal was loaded in the quartz carrier, which was a half-cylinder with a $35-\mathrm{mm}$ external diameter and a $154-\mathrm{mm}$ length. In this study, the effect of different temperatures $\left(425^{\circ} \mathrm{C}\right.$ and $\left.500^{\circ} \mathrm{C}\right)$ on the emission of air pollutants was investigated. In addition to the combustion experiments on the three different charcoals (charcoal briquettes, longan charcoal, and binchotan), combustion experiments with oil (lard oil, BBQ sauce, or a mixture of lard oil and BBQ sauce (1:1)) dripping on the burned charcoals were conducted to explore the effect of oil dripping on the emission of air pollutants. The hot flue gas exhausted from the combustion chamber was cooled to $<43^{\circ} \mathrm{C}$ using cooling water.

The $\mathrm{PM}_{2.5}$ in the flue gas was measured continuously by an environmental particulate air monitor (Model EPAM-5000; HAZ-DUST ${ }^{\circledR}$ ) for 60 minutes. The EPAM-5000 used in this 


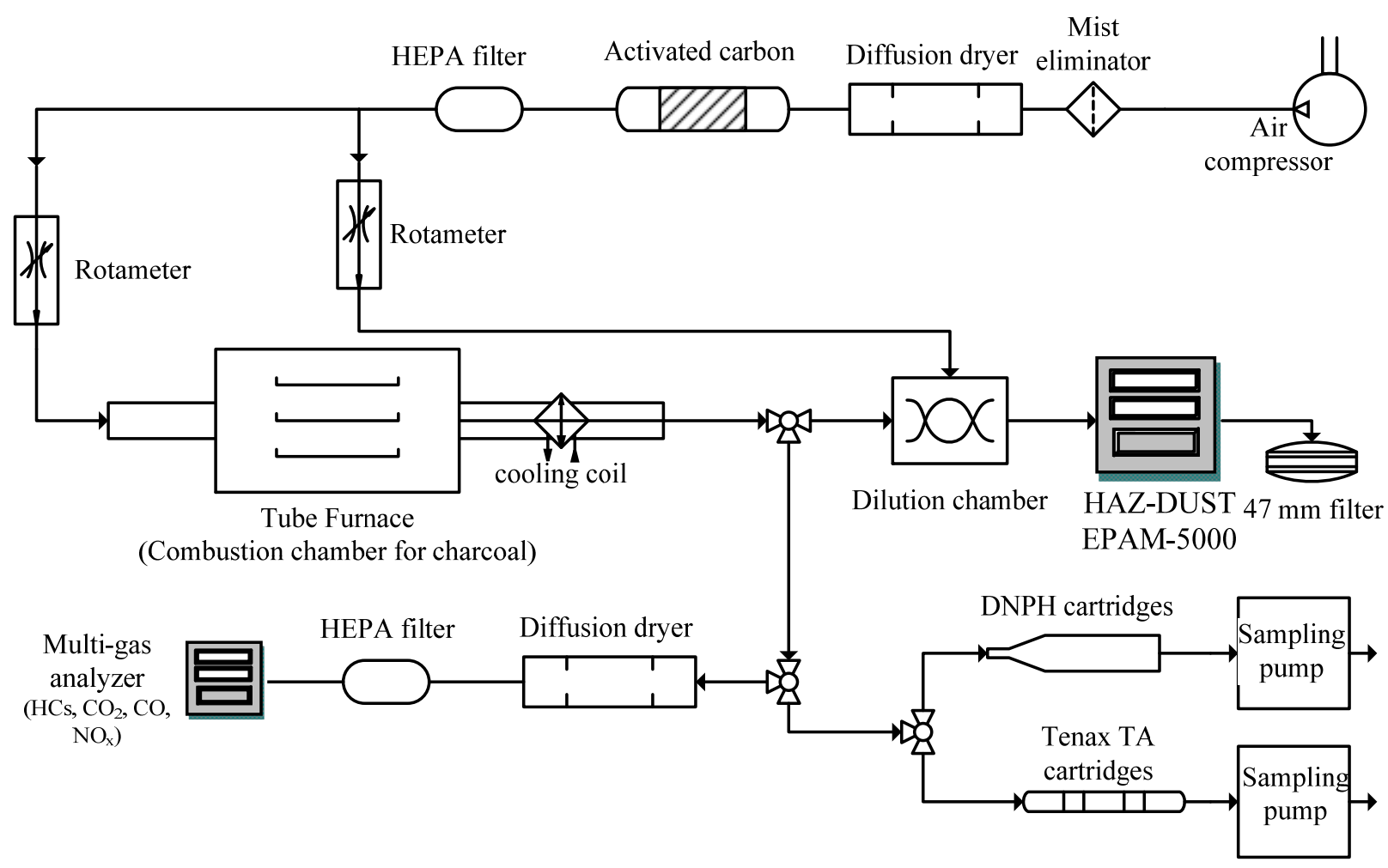

Fig. 1. Schematic of the experimental setup.

study has a unique sampling design. This design allows for real-time data and filter-based gravimetric analysis utilizing the Federal Reference Method (FRM) 47-mm cassette located directly behind the optical sensor for aerosol particles. The sampling flow rate of the EPAM-5000 can be adjusted between 1 and $4.3 \mathrm{~L} \mathrm{~min}^{-1}$. The $\mathrm{PM}_{2.5}$ probe was used during sampling, and the sampling flow velocity was adjusted to $8.5 \mathrm{~cm} \mathrm{~s}^{-1}$ (the same as that in the combustion chamber) to create isokinetic conditions to retain the same particle size distribution. The 47-mm filters collected from $\mathrm{PM}_{2.5}$ sampling by EPAM-5000 were conditioned in desiccators and then digested in a Teflon tube with $20 \mathrm{~mL}$ of extraction solution by a microwave digestion system. The filter sample was heated to $140 \pm 5^{\circ} \mathrm{C}$ and maintained at this temperature for 13 minutes. The digested solution was filtered by a $0.45-\mu \mathrm{m}$ membrane filter, injected into a clean sample tube and adjusted to $20 \mathrm{~mL}$. The sample tube was then analyzed by inductively coupled plasma optical emission spectrometry (ICP-OES) for 15 heavy metals, namely, Al, As, Be, Cd, Co, $\mathrm{Cu}, \mathrm{Fe}, \mathrm{Hg}, \mathrm{Ni}, \mathrm{Pb}, \mathrm{Se}, \mathrm{V}$ and $\mathrm{Zn}$, by the method of NIEA A306.10C of the Taiwan Environmental Protection Agency.

Gaseous air pollutants (total $\mathrm{HCs}, \mathrm{CO}_{2}, \mathrm{CO}$, and $\mathrm{NO}_{x}$ ) in the flue gas were measured continuously by a multigas analyzer (HM5000; Infrared Industries, USA) for 60 minutes. The moisture and particles were removed by a diffusion dryer and a HEPA filter before measurement to protect the multigas analyzer.

The gaseous carbonyl compounds (formaldehyde and acetaldehyde) generated from charcoal combustion were collected on LpDNPH (2,4-dinitrophenylhydrazone) S10 air monitoring cartridges (Supelco, USA), and the sampling flow rate was set at $0.5 \mathrm{~L} \mathrm{~min}^{-1}$ to avoid breakthrough of gaseous carbonyl compounds. After sampling, the DNPH cartridge was eluted with $2 \mathrm{~mL}$ of acetonitrile, and the eluate was adjusted to $10 \mathrm{~mL}$. The DNPH-carbonyl derivatives were analyzed by injecting $10 \mu \mathrm{L}$ of eluate to a 1200 Series HPLC equipped with a diode array detector (DAD) (Agilent, USA) and were quantified by the absorbance at $360 \mathrm{~nm}$. An Agilent C18 column $(250 \times 4.6 \mathrm{~mm}, 5 \mu \mathrm{m})$ (Agilent, USA) served as a reversed-phase column for the separation of DNPH-carbonyl derivatives. The mobile phase contained two solvents: Mixture A, 40:60 (v/v) pure water/acetonitrile, and Solvent B, 100\% acetonitrile. The gradient program started with Mixture A for 7 minutes, followed by a linear gradient from Mixture A to Solvent B over 13 minutes. The flow rate was maintained at $1.0 \mathrm{~mL} \mathrm{~min}{ }^{-1}$ throughout the analysis. Calibration curves $\left(\mathrm{R}^{2} \geq 0.995\right)$ for quantification of formaldehyde and acetaldehyde were prepared by diluting the TO11/IP-6A Aldehyde/Ketone-DNPH Mix (certified reference material, $15 \mu \mathrm{g} \mathrm{mL}^{-1}$ in acetonitrile; Supelco) with pure acetonitrile solvent into a series of concentrations. The detailed QA/QC procedure for carbonyl compound analysis was described in our previous study. The recovery and limit of detection (LOD) for formaldehyde were 99.6-106.3\% and $3.1 \mathrm{ppb}$, respectively, while those for acetaldehyde were 99.6-105.6\% and $2.6 \mathrm{ppb}$, respectively.

The gaseous aromatic compounds (benzene and toluene) produced from charcoal combustion were collected on Tenax TA (60/80 mesh) cartridges (Supelco). The sampling flow rate of the Tenax TA (60/80 mesh) cartridges was controlled at $0.05 \mathrm{~L} \mathrm{~min}^{-1}$ to avoid breakthrough of the gaseous pollutants. After sampling, the Tenax TA cartridges 
were thermally desorbed, and the aromatics were cryofocused using a Tekmar 6000 AERO Trap desorber. Then, the aromatic compounds were analyzed using an Agilent $6890 \mathrm{~N}$ gas chromatograph with a flame ionization detector (GC-FID). A 30-m SPB-5 column (Supelco) with a 0.53-mm inner diameter and a $0.5-\mu \mathrm{m}$ film thickness was used. The quantification of aromatic compounds was conducted as follows. First, we prepared a series of reference solutions diluted from the EPA TO-1 Toxic Organic Mix 1A solution (certified reference material, $2 \mathrm{mg} \mathrm{mL}^{-1}$ each component in methanol; Supelco). Then, we introduced $1 \mu \mathrm{L}$ of the reference solution into a 125-mL glass sampling bulb (Supelco). Once the reference solution was evaporated, the air in the sampling bulb was swilled out by cylinder-compressed air, sampled with a Tenax TA cartridge at a flow rate of $25 \mathrm{~mL} \mathrm{~min}{ }^{-1}$ for 10 minutes, and then analyzed by the GC system. Calibration curves for the quantification of aromatic compounds were generated based on the analytical results for the series of reference solutions. The recovery and LOD for benzene were $93.6-108.3 \%$ and $15 \mathrm{ppb}$, respectively, while those for toluene were $92.1-107.3 \%$ and $16 \mathrm{ppb}$, respectively.

The hydrocarbons benzene (a human carcinogen), toluene (has neurotoxic properties), formaldehyde (causes cancer of the nasopharynx, leukemia, and irritation of eye and respiratory tract), and acetaldehyde (possibly carcinogenic to humans) were determined because of their severe toxic properties (https://toxnet.nlm.nih.gov/). In addition, the singlering compounds benzene and toluene are precursors of toxic PAHs (Bruinsma and Moulijn, 1988; Shukla and Koshi, 2011), which were commonly found in emissions from charcoal BBQs and BBQ meats (Kabir et al., 2010; Badyda et al., 2017).

The charcoal characteristics were derived from the proximate and elemental analyses and calorific value measurement conducted in our previous study (Huang et al., 2016), and the associated data in Table 1 are adopted from our previous study (Huang et al., 2016). The thermogravimetric analysis (TGA) and differential thermal analysis (DTA) of charcoal briquettes, longan charcoal, and binchotan were conducted by using a DuPont TA Q50 thermogravimetric analyzer with air purging.

\section{Data Analysis and Statistics}

Spearman's rank correlation coefficient was applied to evaluate the correlation between the EFs of all the target air pollutants from charcoal burning. According to the analysis results, the air pollutants with highly correlated EFs had similar emission trends. Therefore, only one representative pollutant was further analyzed to avoid redundant descriptions. A linear regression model was utilized to determine the major factor influencing the EFs of air pollutants during the combustion of charcoal. The EF of each air pollutant was applied as a separate dependent variable. Because EFs may be affected by the combustion temperature, sauces, and charcoal components, the combustion temperature, sauce (Sauce 1 was lard oil, Sauce 2 was BBQ sauce, and Sauce 3 was a mixture of lard oil and BBQ sauce), and charcoal components (the moisture, volatile components, fixed carbon, and ash content) were included in the model as independent variables. We set the $p$-value $<0.05$ as the entry threshold for the variable selection and $p$-value $<0.1$ as the removal cutoff. The results of the linear regression analyses were described with the model-adjusted $\mathrm{R}^{2}$ and unstandardized beta coefficient. The accepted level of statistical significance was a $p$-value $<0.05^{*}$ and $0.01 * *$ (two-sided test). Statistical analysis was conducted using SPSS for Windows, version 20.0 (IBM Corporation, Armonk, New York, USA).

\section{RESULTS AND DISCUSSION}

\section{Emission Rates of Air Pollutants}

Fig. 2 and Table 2 demonstrate the ERs of air pollutants from charcoal burning under different conditions. The ERs of $\mathrm{PM}_{2.5}$, benzene, toluene, formaldehyde, and acetaldehyde changed significantly among different experimental conditions, particularly with/without lard oil and BBQ sauce, and ranged from 2.675 to $103.5 \mathrm{mg} \mathrm{h}^{-1}, 0.05$ to $1.03 \mu \mathrm{g} \mathrm{h}^{-1}, 0.02$ to $0.68 \mu \mathrm{g} \mathrm{h}^{-1}, 0.28$ to $1.90 \mu \mathrm{g} \mathrm{h}^{-1}$, and 0.20 to $7.66 \mu \mathrm{g} \mathrm{h}^{-1}$, respectively. In addition, the fractions of benzene, toluene and formaldehyde among the total hydrocarbons were $0.00003-0.00101 \%, 0.00002-0.00059 \%, 0.00021-0.00658 \%$ and $0.00068-0.05179 \%$, respectively. However, the variations in the ERs of the heavy metal pollutants $(\mathrm{Cr}, \mathrm{Cu}$, and $\mathrm{Fe})$, $\mathrm{CO}, \mathrm{CO}_{2}, \mathrm{NO}_{x}$, and among different experimental conditions were not as obvious as the variations in $\mathrm{PM}_{2.5}$, benzene, toluene, formaldehyde, and acetaldehyde (HCs).

However, the ERs were affected by the mass of the charcoal burned; in other words, as the charcoal mass increased, more air pollutants were generated, leading to higher ERs. To eliminate this effect and obtain the EF of each air pollutant, the ERs of the air pollutants emitted by charcoal burning were normalized to the mass of charcoal burned. Some studies suggest that the ER is a function of stove power ( $W$, $\mathrm{kJ} \mathrm{hr}^{-1}$ ) and the energy density (or calorific value) of the fuel $\left(E_{D}, \mathrm{~kJ} \mathrm{~kg}^{-1}\right)$ and that the fuel-based EF can be calculated as (Johnson et al., 2011):

$E R=\frac{E F}{E_{D}} W$

According to our measurement results, there was a significant positive correlation between $\mathrm{ER}$ and $\mathrm{EF} / \mathrm{E}_{\mathrm{D}}$ (Spearman's rho $=0.649-0.998, p<0.002$ ), even though the measurements were obtained under various experimental conditions; thus, the stove power can be estimated based on this equation.

\section{Emission Factors of Air Pollutants}

Fig. 3 and Table 3 demonstrate the EFs of air pollutants from charcoal burning under different conditions. Among all the metal pollutants, $\mathrm{Al}$ had the highest $\mathrm{EF}$, while acetaldehyde had the highest EF among all the measured organic pollutants. It is noted that the EF of $\mathrm{Zn}$ from the combustion of binchotan was much lower than that from the combustion of other charcoals. In the production process of binchotan, the temperature in the activation phase increases up to $1200^{\circ} \mathrm{C}$ (much higher than the activation temperature for other charcoals); thus, most of the elemental $\mathrm{Zn}$ (boiling point 


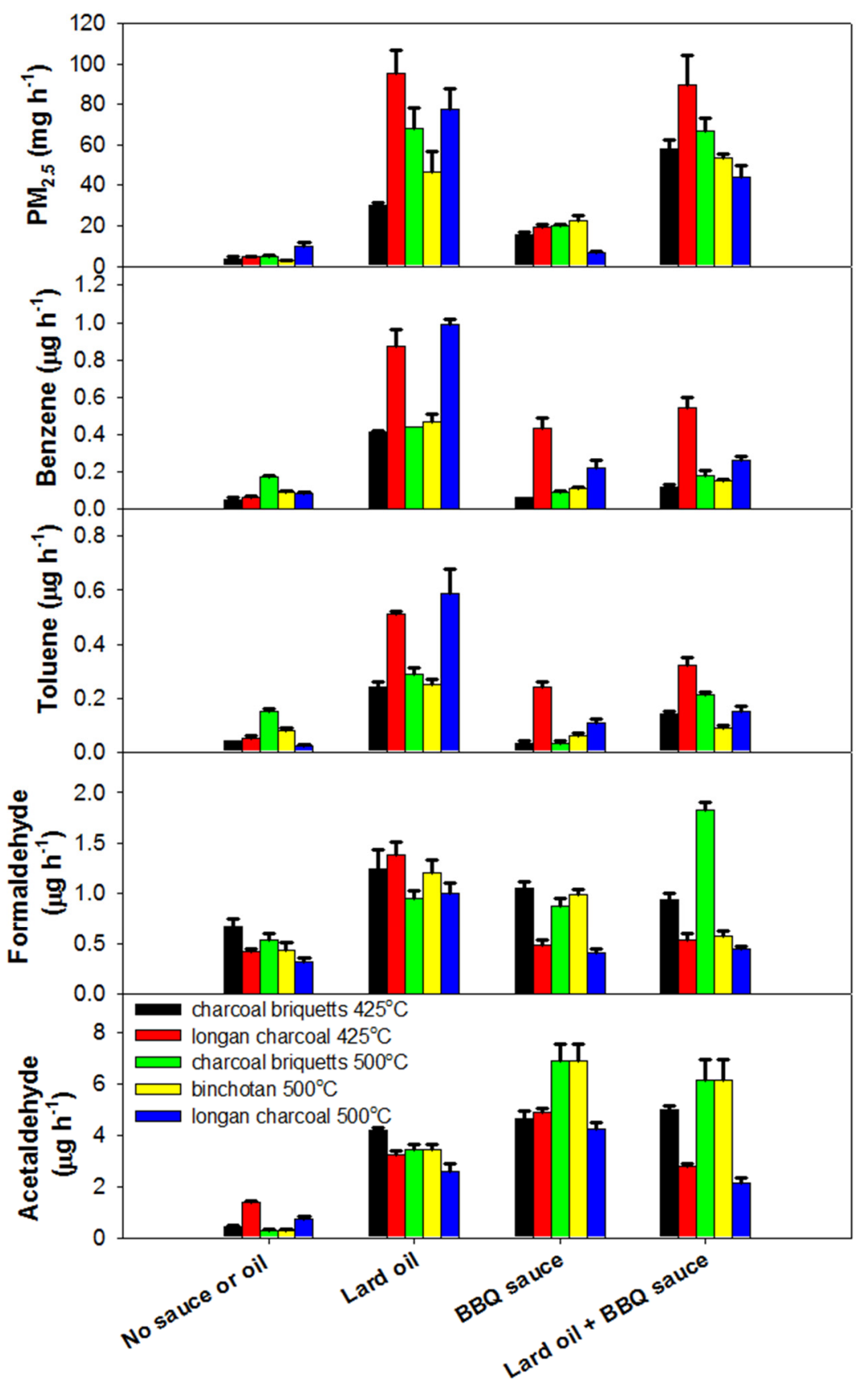

Fig. 2. Effects of lard oil and BBQ sauce on the ERs of various air pollutants from charcoal burning under different conditions.

$=907^{\circ} \mathrm{C}$ ) in binchotan may evaporate during the activation phase. Therefore, the emission of $\mathrm{Zn}$ from binchotan was not as much as those from charcoal briquettes and longan charcoal.

Similar to the ERs, the EFs of $\mathrm{HCs}, \mathrm{PM}_{2.5}$, benzene, toluene, formaldehyde and acetaldehyde varied considerably among different experimental conditions, especially with/ without lard oil and BBQ sauce, and ranged from 622.6$15,667.8 \mathrm{mg} \mathrm{kg}^{-1}, 134.3-5291.1 \mathrm{mg} \mathrm{kg}^{-1}, 2.23-49.17 \mu \mathrm{g} \mathrm{kg}^{-1}$, 1.05 to $32.08 \mu \mathrm{g} \mathrm{kg}^{-1}, 18.8$ to $87.1 \mu \mathrm{g} \mathrm{kg}^{-1}$ and 10.2 to $380.4 \mu \mathrm{g} \mathrm{kg}^{-1}$, respectively. The EFs of the HC compounds were compatible with the results from our previous study (Huang et al., 2016) and other studies on the HC emissions from burning biomass (Andreae and Merlet, 2001), charcoal
(Bhattacharya et al., 2002b), and wood (Bhattacharya et al., 2002b; Evtyugina et al., 2014). It is noted that, when the oil and sauce were applied to the charcoals, the EFs of the HC compounds significantly increased.

When oil or sauce was dripped onto the charcoal, the $\mathrm{PM}_{2.5}$ EFs ranged between 3080.39 and $5291.14 \mathrm{mg} \mathrm{kg}^{-1}$, which was 8-19 times higher than the $\mathrm{PM}_{2.5}$ EF range without sauce dripping. Therefore, the $\mathrm{PM}_{2.5}$ EFs observed in this study were much higher than those observed in our previous study (Huang et al., 2016). Not only the HC and $\mathrm{PM}_{2.5}$ EFs but also the EFs of other target pollutants, including benzene, toluene, formaldehyde and acetaldehyde, increased significantly when the sauce was added to the 


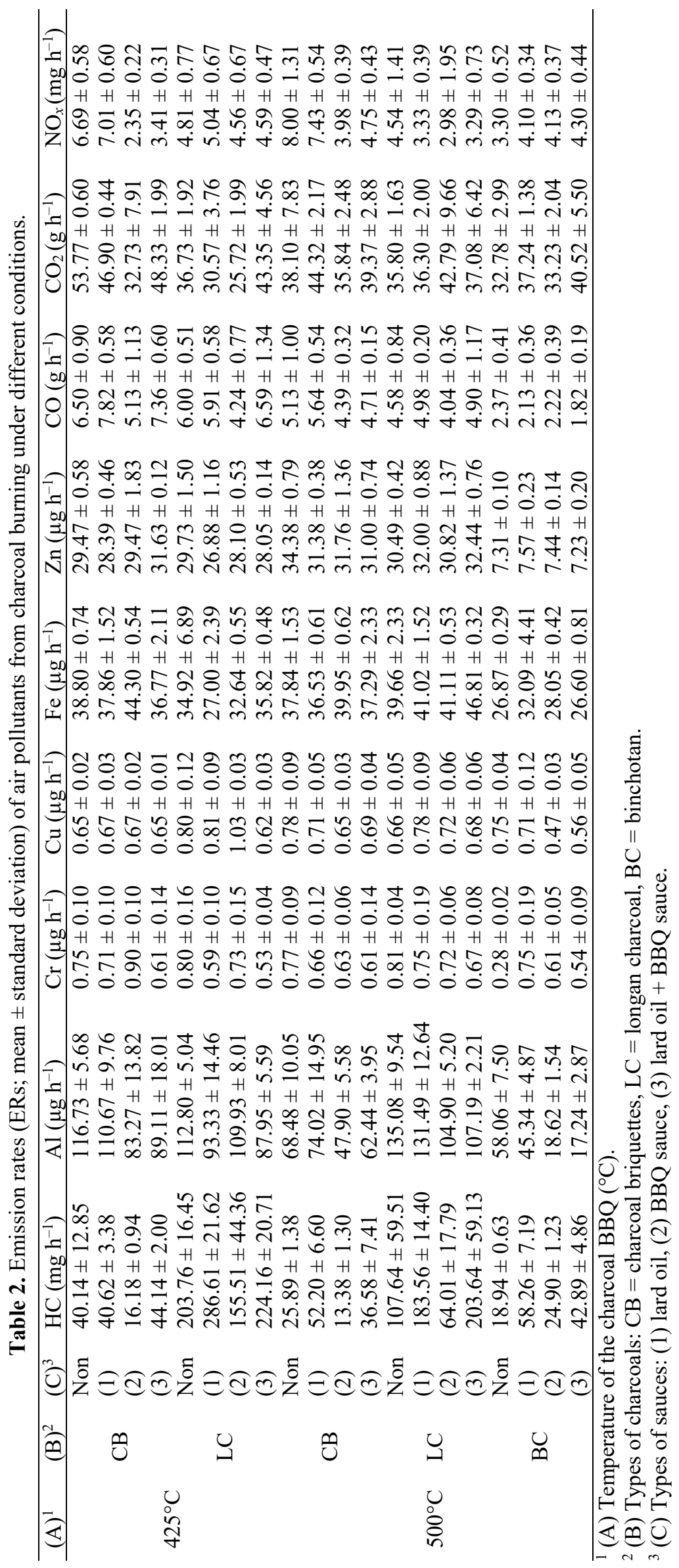




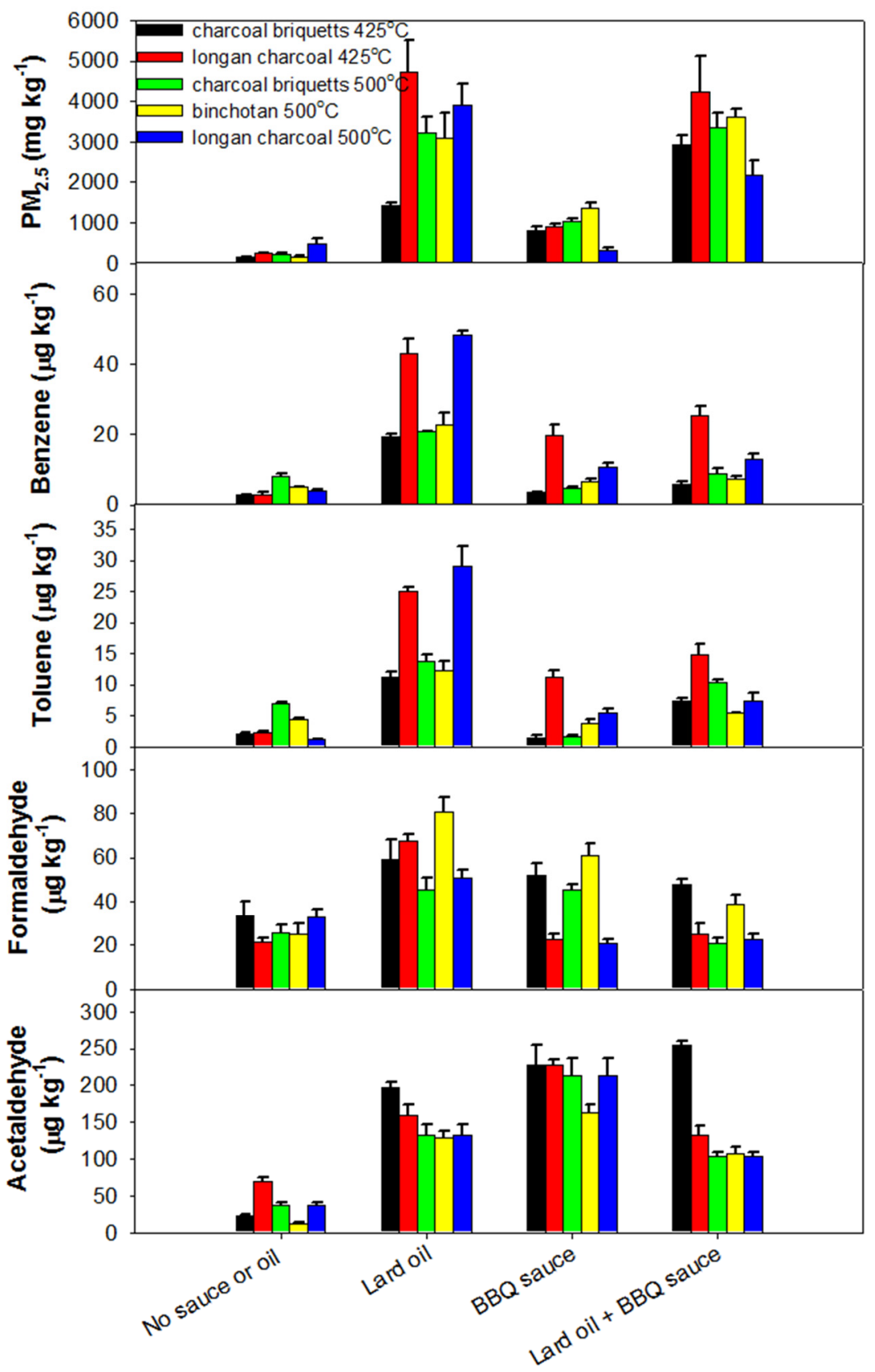

Fig. 3. Effects of lard oil and BBQ sauce on the EFs of various air pollutants from charcoal burning under different conditions.

charcoal. Conversely, the variation in the EFs of $\mathrm{CO}, \mathrm{CO}_{2}$, $\mathrm{NO}_{\mathrm{x}}$, and some metals $(\mathrm{Cr}, \mathrm{Cu}, \mathrm{Fe})$ among the different experimental settings was not substantial.

\section{Correlations between the Emission Factors of Different Air Pollutants}

The results of the correlation analysis between the EFs of all the target air pollutants from charcoal burning are presented in Table 4. The EFs of benzene and toluene were highly positively correlated. Both toluene and benzene are the main ingredients of VOCs in charcoal exhaust gases (Kabir et al., 2010). The $\mathrm{EF}$ of $\mathrm{HC}$ also demonstrated a significant positive correlation with the EFs of toluene and benzene. In addition, the $\mathrm{PM}_{2.5} \mathrm{EF}$ was significantly positively correlated with the EFs of benzene, toluene, formaldehyde, acetaldehyde, and HC compounds.

Among all the metal pollutants emitted from charcoal combustion, there was a significant positive correlation between the EFs of Fe and $\mathrm{Cr}, \mathrm{Fe}$ and $\mathrm{Zn}$, and $\mathrm{Al}$ and $\mathrm{Zn}$. A marginally significant positive correlation between the Fe and $\mathrm{Cr}$ emitted from charcoal products has been reported by Kabir et al. (2011). However, it is curious that there were no significant correlations between the EFs of the $\mathrm{PM}_{2.5}$ metals and the $\mathrm{PM}_{2.5}$ EF. In the study by Dionisio et al. (2012), there was a weak correlation between an indirect method of estimating personal $\mathrm{PM}_{2.5}$ exposure (i.e., applying the relationship between cooking-area $\mathrm{PM}_{2.5}$ and $\mathrm{CO}$ to personal $\mathrm{CO}$ measures) and a direct method of measuring personal $\mathrm{PM}_{2.5}$ for children in Gambia. 


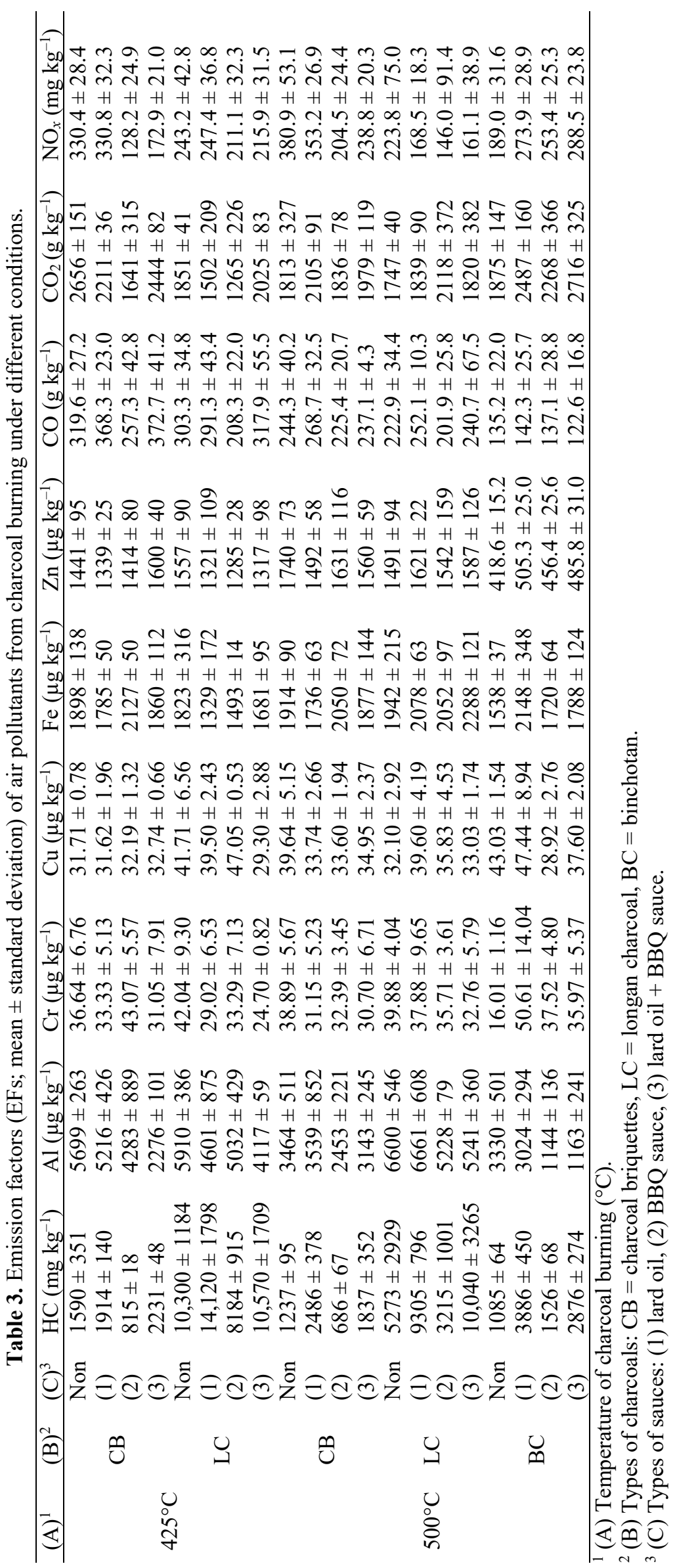




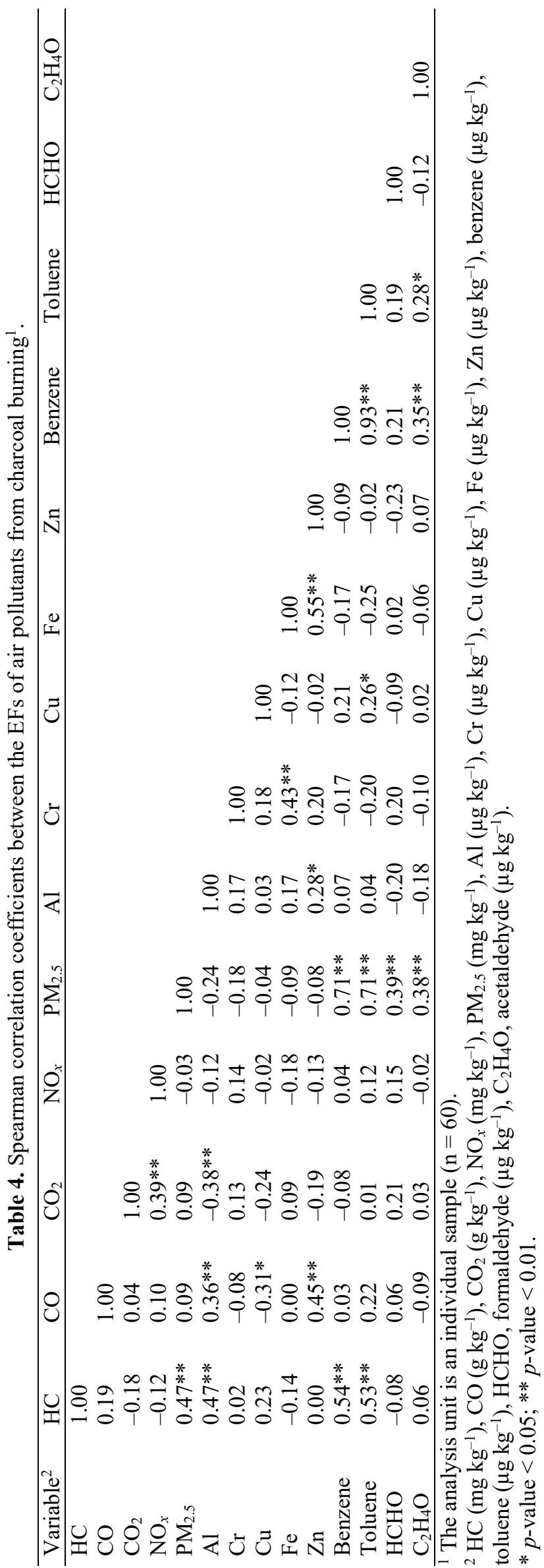

\section{Effect of Temperature on the Emission Factors of Air Pollutants}

The main objective of this study was to investigate the effects of temperature, oil, sauce, and charcoal components (moisture, volatile matter, fixed carbon, and ash) on the emission of air pollutants from charcoal BBQs. A linear regression model was used to evaluate the correlation between these influential factors and the EFs of air pollutants, and Table 5 shows the results of the linear regression analysis.

Increasing the combustion temperature of the charcoals from $425^{\circ} \mathrm{C}$ to $500^{\circ} \mathrm{C}$ significantly reduced the EFs of $\mathrm{HC}$ compounds, formaldehyde, and $\mathrm{CO}$, as presented in Table 5. Our previous study also demonstrated that the EFs of HC compounds decreased significantly when the combustion temperature of sawdust briquette charcoal increased from $450^{\circ} \mathrm{C}$ to $500^{\circ} \mathrm{C}$ (Huang et al., 2016). Venkataraman and Rao (2001) also showed a negative correlation between the $\mathrm{EF}$ of $\mathrm{CO}$ and the combustion temperature of biofuel. Raising the temperature can promote complete combustion (Venkataraman and Rao, 2001) and thus decrease the emission of organic compounds (HCs, formaldehyde and acetaldehyde) and CO.

The TGA and DTA results in Fig. 4 help explain the correlations between the combustion condition (especially temperature) and pollutant emissions. As shown in Fig. 4, the weight loss from 35 to $100^{\circ} \mathrm{C}$ was caused by the loss of moisture. In the DTA curve of longan charcoal, the peak at $396^{\circ} \mathrm{C}$ was associated with the loss of volatile matter. For charcoal briquettes and binchotan, the loss of volatile matter occurred at approximately $100-420^{\circ} \mathrm{C}$ and $100-450^{\circ} \mathrm{C}$, respectively. This result may explain why the emission of $\mathrm{HC}$ at $425^{\circ} \mathrm{C}$ was higher than that at $500^{\circ} \mathrm{C}$. The peaks at $465^{\circ} \mathrm{C}$ and $450^{\circ} \mathrm{C}$ in the DTA curves of charcoal briquettes and longan charcoal resulted from the loss and combustion of fixed carbons. The loss and combustion of fixed carbon that occurred at $561^{\circ} \mathrm{C}$ in the DTA curves of binchotan may explain why binchotan is not flammable at $425^{\circ} \mathrm{C}$.

More efficient stoves with higher combustion temperatures may decrease $\mathrm{PM}_{2.5}$ emissions compared with open fires but increase other potentially more toxic emissions such as ultrafine PM, black carbon, and PAHs (L'Orange et al., 2012). Similarly, charcoal burning may reduce PM but increase CO exposure (Lu et al., 2009).

However, raising the combustion temperature may promote the release of metals from the charcoal, significantly enhancing the EFs of $\mathrm{Fe}$ and $\mathrm{Zn}$ when the combustion temperature of the charcoal increased from $425^{\circ} \mathrm{C}$ to $500^{\circ} \mathrm{C}$.

\section{Effect of Charcoal Proximate Composition on the Emission Factors of Air Pollutants}

As demonstrated in Table 5, the moisture content of the charcoal was significantly positively correlated with the EF of HCs but negatively correlated with the EF of acetaldehyde. Many previous studies have demonstrated that higher moisture content in fuel reduces the burning rate and combustion efficiency of stoves (Bhattacharya et al., 2002a; Yuntenwi et al., 2008; Huangfu et al., 2014), which may lead to more $\mathrm{HC}$ emissions. 
The volatile content in the charcoal was significantly positively correlated with the EFs of $\mathrm{HCs}, \mathrm{PM}_{2.5}$, and benzene, as shown in Table 5, indicating that the volatile matter in charcoal may emit as $\mathrm{HC}$ and $\mathrm{PM}_{2.5}$ during combustion.
Chen et al. (2006) also demonstrated that the EFs of organic carbon and PM increased with the volatile matter content of coal when the volatile matter content was below $30 \%$.

Moreover, the volatile matter content in the charcoal was

Table 5. Linear regression analysis with the air pollutant EFs under different charcoal BBQ conditions as the dependent variables $(n=60)$.

\begin{tabular}{|c|c|c|c|c|c|c|}
\hline \multirow{3}{*}{$\begin{array}{l}\text { Pollutants }^{\mathrm{a}} \\
\text { Variables }^{\mathrm{c}}\end{array}$} & \multicolumn{3}{|c|}{$\mathrm{HC}, \mathrm{R}^{2}=0.84$} & \multicolumn{3}{|c|}{$\mathrm{PM}_{2.5}, \mathrm{R}^{2}=0.798$} \\
\hline & \multirow{2}{*}{$\mathrm{B}^{\mathrm{b}}$} & \multicolumn{2}{|c|}{$95 \% \mathrm{CI}$} & \multirow{2}{*}{$\mathrm{B}$} & \multicolumn{2}{|c|}{$95 \% \mathrm{CI}$} \\
\hline & & Lower & Upper & & Lower & Upper \\
\hline Temp $\left({ }^{\circ} \mathrm{C}\right)$ & $-26.06^{* *}$ & -39.75 & -12.37 & -1.03 & -6.76 & 4.71 \\
\hline Sauce_(1) & $2444.21 * *$ & 1145.74 & 3742.69 & $3023.73 * *$ & 2479.47 & 3568.00 \\
\hline Sauce_(2) & -1012.11 & -2310.59 & 286.37 & $631.08 *$ & 86.82 & 1175.34 \\
\hline Sauce_(3) & $1612.59 *$ & 314.11 & 2911.06 & $3010.09 * *$ & 2465.83 & 3554.36 \\
\hline Moisture & $435.41 * *$ & 221.78 & 649.05 & 78.79 & -10.76 & 168.34 \\
\hline \multirow[t]{2}{*}{ Volatile } & $423.64 * *$ & 365.16 & 482.11 & $25.36^{*}$ & 0.85 & 49.87 \\
\hline & \multicolumn{3}{|c|}{$\mathrm{NO}_{x}, \mathrm{R}^{2}=0.392$} & \multicolumn{3}{|c|}{ Benzene, $\mathrm{R}^{2}=0.808$} \\
\hline Temp $\left({ }^{\circ} \mathrm{C}\right)$ & -0.01 & -0.49 & 0.48 & -0.01 & -0.05 & 0.04 \\
\hline Sauce_(1) & 1.30 & -45.06 & 47.66 & $26.20 * *$ & 21.87 & 230.94 \\
\hline Sauce_(2) & $-84.82 * *$ & -131.18 & -38.46 & $4.45 * *$ & 0.12 & 8.79 \\
\hline Sauce_(3) & $-58.00 *$ & -104.36 & -11.64 & $7.54 * *$ & 3.21 & 11.88 \\
\hline Moisture & -4.01 & -11.63 & 3.62 & 0.51 & -0.20 & 1.22 \\
\hline \multirow[t]{2}{*}{ Volatile } & $-3.80 * *$ & -5.89 & -1.71 & $0.69 * *$ & 0.49 & 0.88 \\
\hline & \multicolumn{3}{|c|}{$\mathrm{HCHO}, \mathrm{R}^{2}=0.539$} & \multicolumn{3}{|c|}{$\mathrm{C}_{2} \mathrm{H}_{4} \mathrm{O}, \mathrm{R}^{2}=0.539$} \\
\hline Temp $\left({ }^{\circ} \mathrm{C}\right)$ & $-0.96 * *$ & -1.35 & -0.56 & $-0.55^{*}$ & -0.04 & -1.06 \\
\hline Sauce_(1) & $62.83 * *$ & 25.59 & 100.06 & $82.96^{* *}$ & 34.47 & 131.46 \\
\hline Sauce_(2) & $49.83 * *$ & 12.59 & 87.06 & $156.71 * *$ & 108.22 & 205.21 \\
\hline Sauce_(3) & $46.68^{*}$ & 9.44 & 83.91 & $93.94 * *$ & 45.44 & 142.43 \\
\hline Moisture & -4.39 & -10.51 & 1.74 & $-10.54 *$ & -18.51 & -2.56 \\
\hline \multirow[t]{2}{*}{ Volatile } & $-4.17 * *$ & -5.85 & -2.49 & -0.33 & -2.52 & 1.85 \\
\hline & \multicolumn{3}{|c|}{$\mathrm{CO}_{2}, \mathrm{R}^{2}=0.32$} & \multicolumn{3}{|c|}{$\mathrm{CO}, \mathrm{R}^{2}=0.76$} \\
\hline Temp $\left({ }^{\circ} \mathrm{C}\right)$ & -0.56 & -3.16 & 2.04 & $-0.91 * *$ & -1.20 & -0.62 \\
\hline Sauce_(1) & 40.33 & -206.35 & 287.01 & 19.48 & -8.09 & 47.04 \\
\hline Sauce_(2) & -163.11 & -409.78 & 83.57 & $-39.09 *$ & -66.66 & -11.53 \\
\hline Sauce_(3) & 208.36 & -38.32 & 455.04 & 13.15 & -14.41 & 40.72 \\
\hline $\mathrm{FC}$ & $38.63 * *$ & 22.31 & 54.95 & $-4.70 * *$ & -6.52 & -2.87 \\
\hline \multirow[t]{2}{*}{ Ash } & 0.18 & -18.85 & 19.21 & $7.75 * *$ & 5.62 & 9.87 \\
\hline & \multicolumn{3}{|c|}{$\mathrm{Al}, \mathrm{R}^{2}=0.73$} & \multicolumn{3}{|c|}{$\mathrm{Cu}, \mathrm{R}^{2}=0.14$} \\
\hline Temp $\left({ }^{\circ} \mathrm{C}\right)$ & -1.34 & -7.91 & 5.23 & -0.01 & -0.05 & 0.04 \\
\hline Sauce_(1) & -392.52 & -1015.98 & 230.94 & 0.75 & -3.41 & 4.90 \\
\hline Sauce_(2) & $-1372.85 * *$ & -1996.31 & -749.39 & -2.12 & -6.28 & 2.04 \\
\hline Sauce_(3) & $-1812.72 * *$ & -2436.18 & -1189.26 & -4.11 & -8.27 & 0.05 \\
\hline $\mathrm{FC}$ & $-210.48^{* *}$ & -251.74 & -169.22 & 0.09 & -0.19 & 0.36 \\
\hline \multirow[t]{2}{*}{ Ash } & 4.69 & -43.41 & 52.79 & $-0.46^{*}$ & -0.78 & -0.14 \\
\hline & \multicolumn{3}{|c|}{$\mathrm{Fe}, \mathrm{R}^{2}=0.13$} & \multicolumn{3}{|c|}{$\mathrm{Zn}, \mathrm{R}^{2}=0.94$} \\
\hline Temp $\left({ }^{\circ} \mathrm{C}\right)$ & $3.24 * *$ & 1.35 & 5.12 & $2.31 * *$ & 1.50 & 3.13 \\
\hline Sauce_(1) & -8.05 & -187.04 & 170.94 & -73.74 & -151.26 & 3.78 \\
\hline Sauce_(2) & 65.23 & -113.76 & 244.22 & -63.64 & -141.16 & 13.88 \\
\hline Sauce_(3) & 75.6 & -103.31 & 254.66 & -19.46 & -96.98 & 58.06 \\
\hline $\mathrm{FC}$ & -8.47 & -20.31 & 3.38 & $-63.27 * *$ & -68.40 & -58.14 \\
\hline Ash & $15.39 *$ & 1.58 & 29.20 & $63.69 * *$ & 57.71 & 69.67 \\
\hline
\end{tabular}

${ }^{\mathrm{a}} \mathrm{HC}\left(\mathrm{mg} \mathrm{kg}^{-1}\right), \mathrm{CO}\left(\mathrm{g} \mathrm{kg}^{-1}\right), \mathrm{NO}_{x}\left(\mathrm{mg} \mathrm{kg}^{-1}\right), \mathrm{PM}_{2.5}\left(\mathrm{mg} \mathrm{kg}^{-1}\right)$, benzene $\left(\mu \mathrm{g} \mathrm{kg}^{-1}\right), \mathrm{HCHO}\left(\mu \mathrm{g} \mathrm{kg}^{-1}\right), \mathrm{CO}_{2}\left(\mathrm{~g} \mathrm{~kg}^{-1}\right)$, $\mathrm{C}_{2} \mathrm{H}_{4} \mathrm{O}\left(\mu \mathrm{g} \mathrm{kg}^{-1}\right), \mathrm{Al}\left(\mu \mathrm{g} \mathrm{kg}^{-1}\right), \mathrm{Cr}\left(\mu \mathrm{g} \mathrm{kg}^{-1}\right), \mathrm{Cu}\left(\mu \mathrm{g} \mathrm{kg}^{-1}\right), \mathrm{Fe}\left(\mu \mathrm{g} \mathrm{kg}^{-1}\right), \mathrm{Zn}\left(\mu \mathrm{g} \mathrm{kg}^{-1}\right)$.

${ }^{\mathrm{b}} \mathrm{B}=$ unstandardized beta coefficient.

c Sauce_(1) = lard oil, Sauce_(2) = BBQ sauce, Sauce_(3) = lard oil + BBQ sauce; Water = water content of charcoal $(\%)$; Volatile $=$ volatile content of charcoal; FC $=$ fixed carbon content of charcoal $(\%)$; Ash $=$ ash content of charcoal $(\%)$.

$* p$-value $<0.05 ; * * p$-value $<0.01$. 


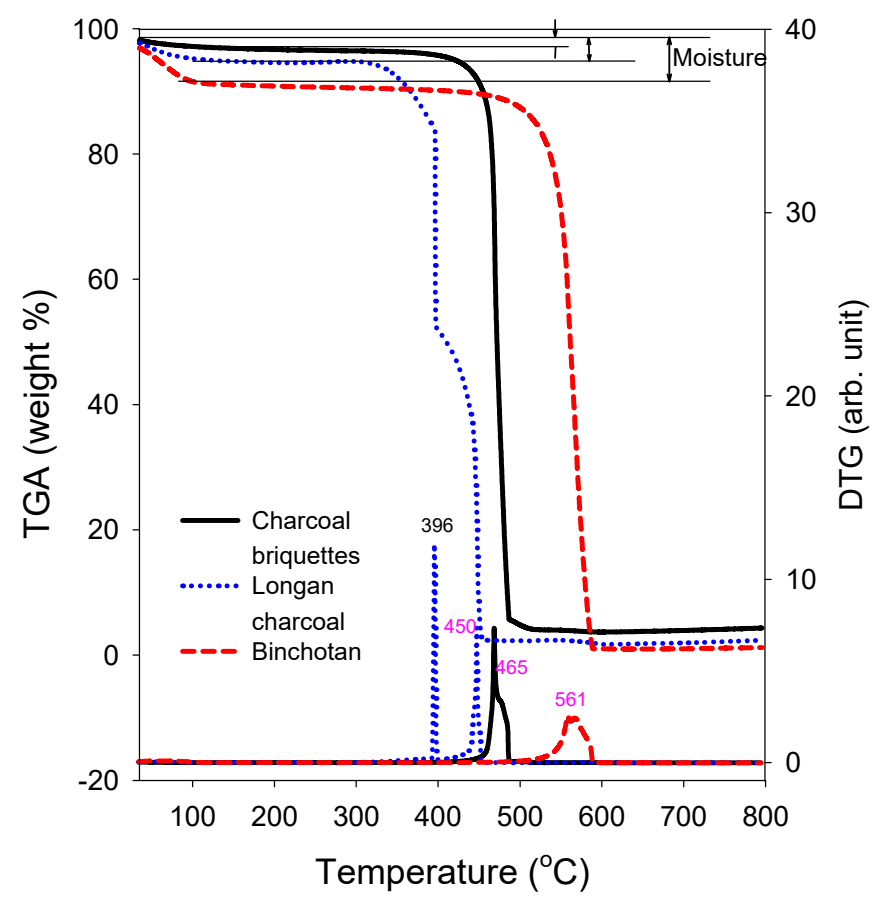

Fig. 4. Thermogravimetric analysis (TGA) and differential thermal analysis (DTA) with air purging of charcoal briquettes, longan charcoal, and binchotan.

negatively correlated with EFs of $\mathrm{NO}_{x}$ and formaldehyde. $\mathrm{NO}_{x}$ emissions during combustion are produced via three major mechanisms: thermal, fuel, and prompt $N O_{\mathrm{x}}$ production (Ryu et al., 2003; Sterner and Turnheim, 2009; Huang et al., 2016). Thermal $\mathrm{NO}_{x}$ is produced from the reaction of nitrogen and oxygen in the combustion air under high temperatures (thermal $\mathrm{NO}_{x}$ is the main mechanism at temperatures above $1377^{\circ} \mathrm{C}$, much higher than the temperatures used in the current study) (Pershing and Wendt, 1977; Ryu et al., 2003); thus, thermal $\mathrm{NO}_{x}$ is negligible in this study (Huang et al., 2016). Meanwhile, fuel $\mathrm{NO}_{x}$ is generated from the oxidation of the nitrogen in fuels, and its production rate is related to the nitrogen content of charcoal (Sterner and Turnheim, 2009; Huang et al., 2016). Prompt $\mathrm{NO}_{x}$ is formed from the prompt collision and reaction of molecular nitrogen with $\mathrm{HCs}$ in fuel-rich flames (Ryu et al., 2003; Sterner and Turnheim, 2009; Huang et al., 2016). The EF of $\mathrm{NO}_{x}$ was positively correlated with the nitrogen content of the charcoal [Spearman rho $\mathrm{r}_{\mathrm{s} 425^{\circ} \mathrm{C}}=0.880 ; \mathrm{r}_{\mathrm{s} 500^{\circ} \mathrm{C}}=0.759$, the data of nitrogen content of the charcoal were adopted from our previous study; Huang et al., 2016), and the peak concentrations of $\mathrm{HCs}$ and $\mathrm{NO}_{x}$ occurred simultaneously. Therefore, both fuel and prompt $\mathrm{NO}_{x}$ might be responsible for the $\mathrm{NO}_{x}$ emissions in this study (Huang et al., 2016).

The fixed carbon content in the charcoal was significantly positively correlated with the EF of $\mathrm{CO}_{2}$, which was a reasonable result, but negatively correlated with the EFs of $\mathrm{CO}, \mathrm{Al}$, and $\mathrm{Zn}$. In our previous study, we found that the carbon content was highly positively correlated with the energy density (or calorific value) of the charcoal (Huang et al., 2016). A higher energy density of the fuel may promote the oxidation of $\mathrm{CO}$ to $\mathrm{CO}_{2}$. Therefore, a negative correlation between the EFs of $\mathrm{CO}$ and the fixed carbon content was found.

The ash content in the charcoal was significantly positively correlated with the EF of CO. A relatively high ash content in charcoal may be unfavorable to combustion and lead to high $\mathrm{CO}$ emissions. In addition, $\mathrm{Fe}$ and $\mathrm{Zn}$ may be two of the main components of ash; therefore, significant positive correlations between the EFs of Fe and Zn, and the charcoal ash content were found.

\section{Effect of Oil and Sauce Drippings on the Emission Factors of Air Pollutants}

Lard oil (Sauce 1) contains approximately $40 \%$ saturated fatty acids and 58\% unsaturated fatty acids (Bitman, 1976) and has a smoke point of $190^{\circ} \mathrm{C}$ (Culinary Institute of America., 2011). When heated, lard oil generates great amounts of fumes and smoke, which may contain polycyclic aromatic HCs, benzene, toluene, formaldehyde, acetaldehyde and PM (Lin and Liou, 2000; Chen and Chen, 2001; Zhu and Wang, 2003; He et al., 2004; Katragadda et al., 2010). Therefore, dripping lard oil on burning charcoal significantly increased the EFs of $\mathrm{HCs}, \mathrm{PM}_{2.5}$, benzene (and toluene), formaldehyde and acetaldehyde, as shown in Table 5.

The major ingredients of BBQ sauce are soy sauce, vinegar, garlic, sugar, salt and water (5.9\% protein, $1.6 \%$ lipids, $25.2 \%$ carbohydrates, $21.9 \%$ sugar, and $2.56 \%$ sodium), and some may also contain sesame oil, rice wine, hot pepper paste, fruit juice, or honey. When burning, these ingredients can considerably contribute to the emission of $\mathrm{PM}_{2.5}$, benzene (and toluene), formaldehyde and acetaldehyde. In addition, BBQ sauces contain a large amount of water, and the increase in the moisture of the charcoal reduces the $\mathrm{CO}$ and $\mathrm{NO}_{x}$ emissions (Bhattacharya et al., 2002a; Huangfu et al., 2014). Therefore, adding BBQ sauce (Sauce 2) to the 
flaming charcoals also significantly enhanced the EFs of $\mathrm{PM}_{2.5}$, benzene (and toluene), formaldehyde and acetaldehyde but reduced the EFs of $\mathrm{NO}_{x}, \mathrm{CO}$, and Al significantly.

The addition of Sauce 3 (the mixture of lard oil and BBQ sauce) to the burning charcoals significantly increased the EFs of HCs, $\mathrm{PM}_{2.5}$, benzene (and toluene), formaldehyde and acetaldehyde but decreased the EFs of $\mathrm{NO}_{x}$ and $\mathrm{Al}$ substantially, and this result demonstrated the comprehensive effect of lard oil and BBQ sauce.

However, to assess the impact of cooking on air quality, emissions of $\mathrm{PM}_{2.5}$ (including organic and black carbon), $\mathrm{CO}$, and other reactive and greenhouse gases from cooking must be quantified as a function of activity and emission factors (or the mass of emitted pollutant per time cooked or fuel used). Emission factors are based on the stove and fuel used. Activity is the information that describes cooking practices, such as the timing and duration of cooking and the types of dishes prepared (Dickinson et al., 2015).

Communities that rely heavily on solid fuels often suffer from elevated indoor and outdoor air pollution. Household emission of pollutants can be an important contributor to ambient air pollution (Chafe et al., 2011).

\section{Limitations}

1. The ventilation rate and charcoal size can affect the ER and EF of airborne pollutants. However, the temperature of the combustion chamber would also be influenced by the ventilation rate and charcoal size. Therefore, the ventilation rate of the combustion chamber was controlled at $17 \mathrm{~min}^{-1}$ and the charcoal size was controlled at 20 $40 \mathrm{~mm}$ to maintain the same temperature conditions. However, the effect of ventilation rate and charcoal size on the ER and EF values cannot be evaluated in this study.

2. The experimental conditions have been modified from the real conditions during the use of charcoal BBQs in the field and may be slightly different from the real conditions.

3. The constituents of foods and additives could affect the emission of air pollutants. However, there are a vast number of possible combinations of constituents of foods and additives, and we only focused on three conditions (lard oil, BBQ sauce, and a mixture of lard oil and BBQ sauce). Many future works should be performed to investigate other conditions during the use of charcoal BBQs.

\section{CONCLUSIONS}

This study systematically investigated the effects of temperature, charcoal components, and dripping oil on the EFs of air pollutants $\left(\mathrm{CO}, \mathrm{CO}_{2}, \mathrm{NO}_{x}\right.$, the total $\mathrm{HCs}$, benzene, toluene, formaldehyde, acetaldehyde, $\mathrm{PM}_{2.5}$, and trace metals in the $\mathrm{PM}_{2.5}$ ) generated from BBQ charcoal. Increases in the combustion temperature decreased the EFs of HCs, formaldehyde, and $\mathrm{CO}$ but increased those of $\mathrm{Fe}$ and $\mathrm{Zn}$. The EF of HCs was significantly positively correlated with both the water and volatile matter content of the charcoal, whereas the EFs of $\mathrm{PM}_{2.5}$ and benzene were significantly positively correlated with only the volatile matter content.
The fixed carbon content of the charcoal was significantly positively correlated with the $\mathrm{EF}$ of $\mathrm{CO}_{2}$ but negatively correlated with those of $\mathrm{CO}, \mathrm{Al}$, and $\mathrm{Zn}$. The EFs of CO, Fe, and $\mathrm{Zn}$ were positively associated with the ash content of the charcoal. Dripping lard oil on the charcoal considerably increased the EFs of $\mathrm{HCs}, \mathrm{PM}_{2.5}$, benzene, formaldehyde, and acetaldehyde. However, dripping BBQ sauce significantly increased the EFs of $\mathrm{PM}_{2.5}$, benzene, formaldehyde, and acetaldehyde but reduced those of $\mathrm{CO}, \mathrm{NO}_{x}$, and $\mathrm{Al}$. To reduce the emission of air pollutants during barbecuing, oil should be prevented from dripping on the charcoal. Furthermore, according to the experimental results, briquettes may be a better choice than longan charcoal or binchotan for barbecuing due to the air pollutant EFs and costs.

\section{ACKNOWLEDGMENTS}

The authors appreciate the Ministry of Science and Technology and the Environmental Protection Administration of Taiwan for providing financial support (Project Numbers MOST-105-EPA-F-001-001 and MOST106-EPA-F-001-001).

\section{REFERENCES}

Abu-Allaban, M., Lowenthal. D.H., Gertler, A.W. and Labib, M. (2007). Sources of $\mathrm{PM}_{10}$ and $\mathrm{PM}_{2.5}$ in Cairo's ambient air. Environ. Monit. Assess. 133: 417-425.

Andreae, M.O. and Merlet, P. (2001). Emission of trace gases and aerosols from biomass burning. Global Biogeochem. Cycles 15: 955-966.

Badyda, A.J., Widziewicz, K., Rogula-Kozłowska, W., Majewski, G. and Jureczko, I. (2017). Inhalation exposure to PM-bound polycyclic aromatic hydrocarbons released from barbecue grills powered by gas, lump charcoal, and charcoal briquettes, In Pulmonary disorders and therapy, Pokorski, M. (Ed.), Springer International Publishing, Cham, pp. 11-27.

Bhattacharya, S., Albina, D. and Khaing, A.M. (2002a). Effects of selected parameters on performance and emission of biomass-fired cookstoves. Biomass Bioenergy 23: 387-395.

Bhattacharya, S., Albina, D. and Salam, P.A. (2002b). Emission factors of wood and charcoal-fired cookstoves. Biomass Bioenergy 23: 453-469.

Bitman, J. (1976). Fat content and composition of animal products. National Research Council, National Academy of Sciences Washington, DC., pp. 200-221.

Boman, J., Lindén, J., Thorsson, S., Holmer, B. and Eliasson, I. (2009) A tentative study of urban and suburban fine particles $\left(\mathrm{PM}_{2.5}\right)$ collected in Ouagadougou, Burkina Faso. X-Ray Spectrom. 38: 354-362.

Bonjour, S., Adair-Rohani, H., Wolf, J., Bruce, N.G., Mehta, S., Pruss-Ustun, A., Lahiff, M., Rehfuess, E.A., Mishra, V. and Smith, K.R. (2013). Solid fuel use for household cooking: Country and regional estimates for 1980-2010. Environ. Health Perspect. 121: 784-790.

Bruinsma, O. and Moulijn, J. (1988). The pyrolytic formation of polycyclic aromatic hydrocarbons from benzene, toluene, 
ethylbenzene, styrene, phenylacetylene and $n$-decane in relation to fossil fuels utilization. Fuel Process. Technol. 18: 213-236.

Chafe, Z., Mehta, S. and Smith, K.R. (2011). Ambient fine particulate $\left(\mathrm{PM}_{2.5}\right)$ air pollution attributable to household cooking fuel in Asia. American Geophysical Union, Fall Meeting 2011, Abstract A54B-03.

Chen, B.H. and Chen, Y.C. (2001). Formation of polycyclic aromatic hydrocarbons in the smoke from heated model lipids and food lipids. J. Agric. Food Chem. 49: 52385243.

Chen, Y., Zhi, G., Feng, Y., Fu, J., Feng, J., Sheng, G. and Simoneit, B.R. (2006). Measurements of emission factors for primary carbonaceous particles from residential rawcoal combustion in China. Geophys. Res. Lett. 33: L20815.

Culinary Institute of America. (2011). The professional chef. John Wiley \& Sons.

Dionisio, K.L., Howie, S.R., Dominici, F., Fornace, K.M., Spengler, J.D., Donkor, S., Chimah, O., Oluwalana, C., Ideh, R.C., Ebruke, B., Adegbola, R.A. and Ezzati, M. (2012). The exposure of infants and children to carbon monoxide from biomass fuels in the Gambia: A measurement and modeling study. J. Exposure Sci. Environ. Epidemiol. 22: 173-181.

Dickinson, K.L., Kanyomse, E., Piedrahita, R., Coffey, E., Rivera, I.J., Adoctor, J., Alirigia, R., Muvandimwe, D., Dove, M., Dukic, V., Hayden, M.H., Diaz-Sanchez, D., Abisiba, A.V., Anaseba, D., Hagar, Y., Masson, N., Monaghan, A., Titiati, A., Steinhoff, D.F., Hsu, Y.Y., Kaspar, R., Brooks, B., Hodgson, A., Hannigan, M., Oduro, A.R. and Wiedinmyer, C. (2015). Research on emissions, air quality, climate, and cooking technologies in Northern Ghana (REACCTING): Study rationale and protocol. BMC Public Health 15: 126.

Evtyugina, M., Alves, C., Calvo, A., Nunes, T., Tarelho, L., Duarte, M., Prozil, S.O., Evtuguin, D.V. and Pio, C. (2014). VOC emissions from residential combustion of southern and mid-European woods. Atmos. Environ. 83: 90-98.

He, L.Y., Hu, M., Huang, X.F., Yu, B.D., Zhang, Y.H. and Liu, D.Q. (2004). Measurement of emissions of fine particulate organic matter from Chinese cooking. Atmos. Environ.38: 6557-6564.

Huang, H.L., Lee, W.M.G. and Wu, F.S. (2016). Emissions of air pollutants from indoor charcoal barbecue. $J$. Hazard. Mater. 302: 198-207.

Huangfu, Y., Li, H., Chen, X., Xue, C., Chen, C. and Liu, G. (2014). Effects of moisture content in fuel on thermal performance and emission of biomass semi-gasified cookstove. Energy Sustainable Dev. 21: 60-65.

Institute for Health Metrics and Evaluation (2017). Global Burden of Disease (GBDx Results Tool). http://ghdx.heal thdata.org/gbd-results-tool. Institute for Health Metrics and Evaluation, USA.

Iqbal, M.A. and Kim, K.H. (2016). Sampling, pretreatment, and analysis of particulate matter and trace metals emitted through charcoal combustion in cooking activities. $\operatorname{Tr} A C$, Trends Anal. Chem. 76: 52-59.

Jetter, J.J. and Kariher, P. (2009). Solid-fuel household cook stoves: characterization of performance and emissions. Biomass Bioenergy 33: 294-305.

Johnson, M., Lam, N., Brant, S., Gray, C. and Pennise, D. (2011). Modeling indoor air pollution from cookstove emissions in developing countries using a Monte Carlo single-box model. Atmos. Environ. 45: 3237-3243.

Kabir, E., Kim, K.H., Ahn, J.W., Hong, O.F. and Sohn, J.R. (2010). Barbecue charcoal combustion as a potential source of aromatic volatile organic compounds and carbonyls. J. Hazard. Mater. 174: 492-499.

Kabir, E., Kim, K.H. and Yoon, H.O. (2011). Trace metal contents in barbeque (BBQ) charcoal products. J. Hazard. Mater. 185: 1418-1424.

Katragadda, H.R., Fullana, A., Sidhu, S. and CarbonellBarrachina, Á.A. (2010). Emissions of volatile aldehydes from heated cooking oils. Food Chem. 120: 59-65.

L'Orange, C., Volckens, J. and DeFoort, M. (2012) Influence of stove type and cooking pot temperature on particulate matter emissions from biomass cook stoves. Energy Sustainable Dev. 16: 448-455.

Lim, S.S., Vos, T., Flaxman, A.D., Danaei, G., Shibuya, K., Adair-Rohani, H., AlMazroa, M.A., Amann, M., Anderson, H.R. and Andrews, K.G. (2012). A comparative risk assessment of burden of disease and injury attributable to 67 risk factors and risk factor clusters in 21 regions, 1990 2010: A systematic analysis for the global burden of disease study 2010. Lancet 380: 2224-2260.

Lin, J.M. and Liou, S.J. (2000). Aliphatic aldehydes produced by heating Chinese cooking oils. Bull. Environ. Contam. Toxicol. 64: 817-824.

Lu, H., Zhu, L. and Zhu, N. (2009). Polycyclic aromatic hydrocarbon emission from straw burning and the influence of combustion parameters. Atmos. Environ. 43: 978-983.

Mahmudur Rahman, M. and Kim, K.H. (2012). Release of offensive odorants from the combustion of barbecue charcoals. J. Hazard. Mater. 215-216: 233-242.

Obioh, I.B., Ezeh, G.C., Abiye, O.E., Alpha, A., Ojo, E.O. and Ganiyu, A.K. (2013) Atmospheric particulate matter in Nigerian megacities. Toxicol. Environ. Chem. 95: 37985.

Ofosu, F.G., Hopke, P.K., Aboh, I.J. and Bamford, S.A. (2013). Biomass burning contribution to ambient air particulate levels at Navrongo in the Savannah zone of Ghana. J. Air Waste Manage. Assoc. 63: 1036-1045.

Pershing, D. and Wendt, J. (1977). Pulverized coal combustion: The influence of flame temperature and coal composition on thermal and fuel $N O_{x}$, Symposium (International) on Combustion, 1977, Elsevier, pp. 389399.

Rooney, M.S., Arku, R.E., Dionisio, K.L., Paciorek, C., Friedman, A.B., Carmichael, H., Zhou, Z., Hughes, A.F., Vallarino, J., Agyei-Mensah, S., Spengler, J.D. and Ezzati, M. (2012) Spatial and temporal patterns of particulate matter sources and pollution in four communities in Accra, Ghana. Sci. Total Environ. 435-436: 107-114.

Ryu, H.J., Lim, N.Y., Bae, D.H. and Jin, G.T. (2003). Carbon deposition characteristics and regenerative ability of oxygen carrier particles for chemical-looping combustion. 
Korean J. Chem. Eng. 20: 157-162.

Shukla, B. and Koshi, M. (2011). Comparative study on the growth mechanisms of PAHs. Combust. Flame 158: 369375.

Smith, K.R., Mehta, S. and Maeusezahl-Feuz, M. (2004). Indoor air pollution from household use of solid fuels. Comparative quantification of health risks: Global and regional burden of disease attributable to selected major risk factors 2: 1435-1493.

Sterner, T. and Turnheim, B. (2009). Innovation and diffusion of environmental technology: Industrial $\mathrm{NO}_{x}$ abatement in Sweden under refunded emission payments. Ecol. Econ. 68: 2996-3006.

Susaya, J., Kim, K.H., Ahn, J.W., Jung, M.C. and Kang, C.H. (2010). BBQ charcoal combustion as an important source of trace metal exposure to humans. J. Hazard. Mater. 176: 932-937.

Taner, S., Pekey, B. and Pekey, H. (2013). Fine particulate matter in the indoor air of barbeque restaurants: Elemental compositions, sources and health risks. Sci. Total.
Environ. 454-455: 79-87.

Venkataraman, C. and Rao, G.U.M. (2001). Emission factors of carbon monoxide and size-resolved aerosols from biofuel combustion. Environ. Sci. Technol. 35: 2100-2107.

World Health Organization (WHO) (2017). Global health risks-mortality and burden of disease attributable to selected major risks. World Health Organization.

Yuntenwi, E.A., MacCarty, N., Still, D. and Ertel, J. (2008). Laboratory study of the effects of moisture content on heat transfer and combustion efficiency of three biomass cook stoves. Energy Sustainable Dev. 12: 66-77.

Zhu, L. and Wang, J. (2003). Sources and patterns of polycyclic aromatic hydrocarbons pollution in kitchen air, China. Chemosphere 50: 611-618.

Received for review, June 10, 2019 Revised, November 14, 2019 Accepted, January 12, 2020 